\title{
Program "Aku Bisa ke Toilet Sendiri" untuk Meningkatkan Keterampilan Toileting Anak Usia Dini
}

\author{
"Aku Bisa ke Toilet Sendiri" Program \\ to Improve Toileting Skill in Early Childhood
}

Putu Riana Artyanti Putri', Wisjnu Martani ${ }^{2}$

1,2Fakultas Psikologi, Universitas Gadjah Mada

\begin{abstract}
Toileting skill is one of the developmental tasks in early childhood to cultivate children autonomy in daily life. The main objective of this study was to find out whether the "Aku Bisa ke Toilet Sendiri" program can improve the ability of early childhood training toilets. The quasi-experiment used in this study was nonequivalent control group design. The participants in this study consisted of 16 students aged 4-6 (8 in experimental group and 8 in control group). The research instrument used in this study were a toileting ability scale, an observation sheet of a child's toileting ability, and a "Aku Bisa ke Toilet Sendiri" program module. Data analysis method applied was independent sample T-test. The results of the analysis showed that, there was no significant difference in scores between the experimental groups that received treatment in the form of the "Aku Bisa Ke Toilet Sendiri" program and the control group which only received treatment in the form of video-themed songs about keterampilan toileting $(\mathrm{t}(14)=1.761 ; \mathrm{p}=0.055, \mathrm{p}>0.05)$.
\end{abstract}

Keywords: early childhood; toileting skill; video modelling

Abstrak. Keterampilan toileting merupakan salah satu tugas perkembangan pada masa anak usia dini untuk melatih kemandirian dalam kehidupan sehari-hari. Maka dirasa perlu untuk membiasakan anak agar dapat melakukan kegiatan toileting secara mandiri. Tujuan utama dari penelitian ini adalah untuk mengetahui apakah program "Aku Bisa ke Toilet Sendiri" dapat meningkatkan keterampilan toileting anak usia dini. Kuasi eksperimen yang digunakan dalam penelitian ini adalah bentuk nonequivalent control group design. Partisipan terdiri dari 16 orang siswa yang berusia 4-6 tahun (8 siswa kelompok eksperimen dan 8 siswa kelompok control). Instrumen penelitian yang digunakan pada penelitian ini adalah skala keterampilan toileting, lembar observasi keterampilan toileting anak, serta modul program "Aku Bisa ke Toilet Sendiri". Analisis data menggunakan independent sample T-test. Hasil analisis menunjukkan $(t(14)=1,761 ; p=0,055, p>0,05)$. Tidak ada perbedaan skor yang signifikan antara kelompok eksperimen yang mendapat perlakuan berupa program "Aku Bisa ke Toilet Sendiri" dengan kelompok kontrol yang hanya mendapat perlakuan berupa pemutaran video yang bertemakan lagu-lagu mengenai keterampilan toileting.

Kata kunci: anak usia dini; keterampilan toileting; modeling video

${ }^{1}$ Korespondensi mengenai artikel ini dapat dilakukan melalui rianaartyantiputri@gmail.com

2atau wisjnu m@ugm.ac.id 
Keterampilan toileting merupakan suatu keterampilan yang menuntut kemandirian dari anak. Anak yang memiliki keterampilan toileting yang baik akan dapat melakukan kegiatan sehari-harinya secara mandiri. Hal tersebut sejalan dengan apa yang diungkapkan oleh Hasballah (2017) yang menyatakan bahwa keterampilan toileting atau latihan pergi ke kamar mandi merupakan suatu usaha awal untuk melatih anak mandiri dalam kehidupan sehari-hari. Anak yang telah mampu toileting dengan baik akan menjadi lebih mandiri karena anak lebih menyadari kebutuhan tubuhnya dan lebih adaptif dalam berkomunikasi dan bersosialisasi di lingkungan sosial (Cocchiola \& Redpath, 2017). Akan tetapi dari hasil studi pendahuluan terlihat bahwa rata-rata dari 15 orang siswa terdapat 2-4 orang siswa atau sekitar 13\% - 26\% siswa di kelas TK kecil yang memiliki rentang usia 46 tahun masih belum cukup mandiri dalam melakukan kegiatan toileting. Melihat hasil tersebut maka muncul pertanyaan mengapa masih ada anak usia prasekolah yang belum memiliki kemandirian dalam melakukan kegiatan toileting?

Mengajarkan anak untuk dapat melakukan kegiatan toileting secara mandiri memerlukan kesiapan, baik secara fisik maupun secara psikologis dari anak itu sendiri. Seperti yang diungkapkan oleh Burns \& Matson (2017) kesiapan anak untuk memulai melaksanakan keterampilan toileting dipengaruhi oleh banyak faktor yang berhubungan dengan kemampuan fisiologis anak (seperti otot dan gerak refleks spinchter) serta kemampuan psikologis anak (seperti kemampuan anak dalam memahami istilah-istilah yang berkaitan dengan kegiatan toileting, adanya ketertarikan anak terhadap kegiatan toileting, serta kemampuan anak untuk memahami bahwa popok yang digunakan sudah kotor). Keterampilan motorik anak juga diperlukan dalam melaksanakan kegiatan toileting. Menurut Brazelton (1962) kemampuan motorik kasar (seperti kemampuan untuk berjalan dan duduk di toilet) serta kemampuan motorik halus (seperti kemampuan untuk menggunakan dan melepaskan pakaian dan membersihkan diri) juga memberi pengaruh terhadap keterampilan toileting anak. Kemampuan tersebut memberikan kebebasan pada kemampuan fisik anak saat menggunakan toilet secara mandiri.

Seperti yang telah disebutkan sebelumnya, selain kematangan fisiologis dan psikologis, beberapa faktor lain juga dapat memengaruhi keterampilan toileting anak. Burns \& Matson (2017) mengungkapkan bahwa keterampilan toileting anak juga dipengaruhi oleh kemampuan kognitif anak, kemampuan ini diperlukan agar anak mampu menghubungkan antara dorongan untuk menghilangkan rasa ingin $\mathrm{BAK}$ atau $\mathrm{BAB}$ dengan tindakan menggunakan toilet. Brazelton (1962) mengungkapkan bahwa kemampuan mengendalikan impuls dapat disebabkan oleh kemampuan sosial dan emosional anak. Keinginan anak untuk menyenangkan orang tua dan meniru perilaku yang sesuai secara sosial sesuai model yang ada serta adanya dorongan emosional untuk mengembangkan otonomi merupakan faktor-faktor sosial yang memberi pengaruh penting dalam mengendalikan kontrol impuls. Burns \& Matson (2017) juga menyebutkan kemampuan komunikasi sebagai salah satu 
faktor yang memengaruhi keterampilan toileting anak. Anak-anak harus memiliki keterampilan bahasa reseptif yang digunakan untuk memahami penjelasan tentang bagaimana cara menggunakan toilet dan langkah apa saja yang harus dilakukan. Kemampuan bahasa ekspresif juga sangat diperlukan agar anak dapat mengkomunikasikan atau mengekspresikan keinginannya untuk pergi ke toilet.

Berdasarkan hasil penelitian yang dilakukan oleh Agustina \& Sapta (2015) disebutkan bahwa salah satu faktor menyebabkan kegagalan toileting training adalah cara mengajarkan keterampilan toileting yaitu sebesar 94,5\%. Melihat pentingnya cara mengajarkan keterampilan toileting terhadap kemandirian anak dalam melakukan kegiatan toileting, maka dirasa penting untuk menyusun metode pembelajaran keterampilan toileting yang dapat meningkatkan keterampilan toileting anak. McLay dan Blampied menyatakan bahwa toileting training adalah proses pembelajaran sosial yang membutuhkan interaksi antara anak-anak, orang tua dan pengasuh mereka. Teori social cognitive Bandura (1977) mengungkapkan bahwa ketika seorang anak mempelajari sesuatu, maka mereka akan dapat mempresentasikan atau mentransformasi pengalaman secara kognitif. Bandura juga mengembangkan model determinisme resiprokal (triadic reciprocal causation) mengasumsikan bahwa tindakan manusia adalah hasil dari interaksi antar tiga variabel yaitu perilaku, person/kognitif, serta lingkungan. Faktor-faktor tersebut saling berinteraksi untuk memengaruhi pembelajaran. Berdasarkan model determinisme resiprokal Bandura, maka peneliti berasumsi bahwa untuk dapat membuat anak mampu melakukan keterampilan toileting secara mandiri maka memerlukan interaksi dari ketiga faktor tersebut, baik dari kesiapan anak itu sendiri, lingkungan sekitar, serta perilaku toileting itu sendiri. Ketika anak mulai diperkenalkan keterampilan toileting maka anak harus memiliki kesiapan baik secara fisik maupun psikologis. Kemudian salah satu hal yang dapat dilakukan oleh lingkungan anak adalah dengan menentukan metode pengajaran yang sesuai untuk melatih anak melakukan toileting, di mana metode ini tidak hanya diterapkan di lingkungan keluarga atau rumah anak tetapi juga diterapkan pada proses belajar anak ketika di sekolah. Berdasarkan penelitian yang dilakukan oleh Drysdale, Lee, Anderson, dan Moore (2015) menunjukkan bahwa metode modeling dengan media video (VM) dapat meningkatkan keterampilan toileting anak dengan spektrum autisme, menunjukkan bahwa salah satu metode pembelajaran keterampilan toileting yang sering digunakan dan menunjukkan hasil yang mampu meningkatkan keterampilan keterampilan toileting adalah dengan menggunakan metode modeling dengan media video.

Dari hasil studi pendahuluan yang menunjukkan bahwa rata-rata dari 15 orang siswa terdapat 2-4 orang siswa atau sekitar $13 \%$ - 26\% siswa di kelas TK kecil yang memiliki rentang usia 4-6 tahun masih belum cukup mandiri dalam melakukan kegiatan toileting. Maka peneliti merasa penting untuk mencari model pembelajaran toileting yang sesuai untuk anak usia 4-6 tahun agar lebih mandiri dalam melakukan 
kegiatan toileting. Selain itu untuk membuat anak mempertahankan kebiasaan keterampilan toileting secara mandiri, maka perlu adanya dukungan dari lingkungan keluarga ataupun caregiver anak. Untuk menambah informasi keluarga ataupun caregiver anak akan pentingnya keberhasilan keterampilan toileting anak, maka orang tua ataupun caregiver serta guru akan diberikan psikoedukasi terkait pentingnya keterampilan toileting dan sikap yang perlu dimunculkan ketika mengajarkan anak keterampilan toileting.

Berdasarkan uraian di atas maka disimpulkan bahwa keterampilan toileting merupakan suatu keterampilan yang terdiri dari beberapa perilaku yang dapat dipelajari. Oleh karena itu untuk mengajarkan anak keterampilan toileting diperlukan strategi yang sesuai agar tetap mempertahankan keterampilan toileting. McLay \& Blampied (2017) serta social cognitive theory Bandura mengungkapkan bahwa perilaku manusia adalah hasil dari interaksi antar tiga faktor yaitu perilaku, person/kognitif, serta lingkungan. Faktorfaktor tersebut saling berinteraksi untuk memengaruhi pembelajaran. Oleh karena itu peneliti berasumsi untuk dapat meningkatkan keterampilan toileting anak maka diperlukan interaksi dari ke tiga faktor tersebut, baik dari kesiapan anak itu sendiri, lingkungan sekitar serta perilaku keterampilan toileting itu sendiri. Ketika anak mulai diperkenalkan keterampilan toileting maka anak harus memiliki kesiapan baik secara fisik dan psikologis. Kemudian salah satu hal yang dapat dilakukan oleh lingkungan anak adalah dengan menentukan metode pengajaran yang sesuai untuk melatih anak melakukan keterampilan toileting, di mana metode ini tidak hanya diterapkan di lingkungan keluarga atau rumah anak tetapi juga diterapkan pada proses belajar anak ketika di sekolah. Berdasarkan penelitian sebelumnya, menunjukkan bahwa salah satu metode pembelajaran keterampilan toileting yang sering digunakan dan menunjukkan hasil yang mampu meningkatkan keterampilan toileting adalah dengan menggunakan metode modeling dengan media video. Selain itu lingkungan keluarga ataupun caregiver anak memiliki peran dalam meningkatkan keterampilan toileting anak.

Oleh karena itu untuk menambah informasi terkait keterampilan toileting anak serta pentingnya keberhasilan keterampilan toileting anak, maka orang tua ataupun caregiver serta guru akan diberikan psikodukasi terkait pentingnya keterampilan toileting dan sikap yang perlu dimunculkan ketika memperkenalkan dan mengajarkan anak keterampilan toileting. Oleh karena itu pada penelitian ini peneliti akan mencoba merancang sebuah program "Aku Bisa ke Toilet Sendiri" yang disusun untuk meningkatkan keterampilan toileting, di mana program yang dirancang tidak hanya melibatkan anak tetapi juga melibatkan orang tua, caregiver, dan guru di sekolah. Program yang dirancang terdiri atas kegiatan psikoedukasi kelompok kepada orang tua atau caregiver serta guru serta menerapkan metode pembelajaran modeling dengan menggunakan media video kepada anak.

\section{Metode}


Variabel tergantung pada penelitian ini adalah keterampilan toileting anak. Keterampilan toileting adalah kemampuan anak dalam mengomunikasikan keinginan pergi ke toilet kemudian anak dapat melakukan buang air kecil dan buang air besar secara mandiri tanpa bantuan orang tua ataupun orang dewasa lainnya sehingga anak tetap kering secara konsisten.

\section{Partisipan penelitian}

Partisipan pada program "Aku Bisa Pergi ke Toilet sendiri" terdiri dari orang tua atau caregiver yang memiliki anak dengan rentang usia 4-6 tahun, serta anak usia 4 sampai 6 tahun yang saat ini ada di jenjang PAUD (Pendidikan Anak Usia Dini). Partisipan dalam program metode pengajaran modeling yang akan digunakan pada penelitian ini berdasarkan pada permasalahan yang ditemukan di lapangan, maka karakteristik partisipan pada penelitian ini adalah: 1) Siswa siswi PAUD yang berada di kabupaten Sleman dengan rentang usia 4 sampai 6 tahun; 2) Memiliki skor kemandirian dalam melakukan keterampilan toileting yang tergolong dalam rentang kategori sedang atau anak yang dari hasil observasi menunjukkan belum dapat melakukan beberapa tahapan keterampilan toileting secara mandiri atau belum melakukannya dengan benar; 3) Tidak dalam perawatan kesehatan khusus; dan 4) Tidak mengalami permasalahan perkembangan dan tidak mengalami penyakit kronis.

Jumlah total partisipan pada penelitian ini sebanyak 16 orang. Kelompok eksperimen sebanyak delapan orang dengan kategori kemampuan toileting dari sedang sampai tinggi, akan tetapi dari hasil observasi, partisipan dengan skor keterampilan toileting tinggi masih belum melakukan tahapan keterampilan toileting secara keseluruhan atau masih mendapat bantuan. Kemudian partisipan pada kelompok kontrol adalah sebanyak delapan orang dengan kategori tinggi akan tetapi dari hasil observasi, partisipan dengan skor keterampilan toileting tinggi masih belum melakukan tahapan keterampilan toileting secara keseluruhan atau masih mendapat bantuan.

\section{Instrumen penelitian}

Instrumen penelitian yang digunakan pada penelitian ini adalah skala keterampilan toileting, panduan observasi keterampilan toileting, serta modul pelaksanaan program "Aku Bisa ke Toilet Sendiri". Skala keterampilan toileting diadopsi dari skala Nurfajriyani, Prabandari, dan Lusmilasari (2016). Nurfrajriyani et al. (2016) mengadopsi toilet skilss assesment yang telah terpublikasi dan guideline keterampilan toileting dari American Academy of Pediatric 2004, yang kemudian diuji coba kembali oleh peneliti. Dari hasil uji coba didapatkan 23 item yang valid dengan validitas isi bergerak di antara 0,73 sampai dengan 0,96, kemudian dari validitas empiris memiliki nilai koefisien korelasi yang berkisar antara 0,321 sampai dengan 0,650 . Hasil reliabilitas skala kemampuan toilet training anak dengan menggunakan Cronbach Alpha $(\alpha)$ adalah sebesar 0,878. Panduan observasi digunakan untuk mengetahui perubahan terkait keterampilan toileting anak sebelum dan sesudah pemberian perlakuan. Penyusunan panduan observasi dikembangkan dari hasil penelitian yang dilakukan oleh Kaerts, Vermandel, 
Tabel 1.

Hasil Uji Validitas Aiken's pada Setiap Modul Perlakuan

\begin{tabular}{lc}
\hline \multicolumn{2}{c}{ Hasil uji validitas Aiken modul dari setiap komponen modul psikoedukasi } \\
\hline Umum & $0,875-0,917$ \\
Konten & $0,75-0,875$ \\
\hline \multicolumn{2}{c}{ Hasil uji validitas Aiken dari setiap komponen modul metode pembelajaran modeling } \\
\hline Umum & $0,875-0,958$ \\
Konten & $0,71-0,917$ \\
\hline
\end{tabular}

Lierman, van Gestel \& Wyndaele (2012) yang membahas tentang tanda-tanda kesiapan anak untuk melakukan keterampilan toileting, yang kemudian oleh peneliti dikembangkan menjadi 24 daftar pernyataan dengan model checklist. Validitas Aiken menunjukkan koefisien aiken's $\mathrm{V}$ bergerak di antara 0,90 sampai dengan 0,99 .

Modul pelaksanaan Program "Aku Bisa ke Toilet Sendiri" terdiri dua perlakuan, yang pertama adalah modul pelaksanaan program psikoedukasi bagi orang tua, caregiver, serta guru. Kemudian modul ke dua merupakan modul metode pembelajaran modeling dengan media video yang dirancang untuk pembelajaran anak di sekolah. Peneliti melakukan uji validitas Aiken terhadap modul psikoedukasi dan modul pembelajaran modeling secara umum dan secara konten. Tabel 1 merangkum hasil uji validitas Aiken terhadap modul.

Hasil uji coba lapangan terhadap modul program "Aku Bisa ke Toilet Sendiri" menunjukkan bahwa terdapat perbedaan yang signifikan antara skor pretest dan posttest skala keterampilan toileting memiliki $p=0,000(p<0,05)$, dengan skor rata-rata setelah pelaksanaan program lebih tinggi dibandingkan skor pelaksanaan sebelum pelaksanaan program (mean pretest $=89,27)$; (mean posttest $=98,27)$.

\section{Prosedur penelitian}

Penelitian ini menggunakan pendekatan kuantitatif dengan metode eksperimen. Metode eksperimen yang digunakan pada penelitian ini adalah metode kuasi eksperimen. Kuasi eksperimen yang digunakan dalam penelitian ini adalah bentuk nonequivalent control group design. Secara lebih rinci desain penelitian pada penelitian ini ditampilkan pada gambar 1 .

Intervensi yang diberikan dalam penelitian ini adalah program "Aku Bisa ke Toilet Sendiri" yang terdiri dari pelaksanaan program psikoedukasi bagi orang tua, caregiver, serta guru. Kemudian yang ke dua adalah penerapan metode pembelajaran modeling dengan media video. Yang dibawakan oleh 1) pembicara yang merupakan seorang psikolog, 2) eksperimenter dan 3) observer. 


\begin{tabular}{cccc}
\hline Kelompok & Pretest & Perlakuan & Posttest \\
\hline KE & $\mathrm{O}_{1}$ & $\mathrm{X}$ & $\mathrm{O}_{2}$ \\
KK & $\mathrm{O}_{3}$ & & $\mathrm{O}_{4}$ \\
\hline
\end{tabular}

\section{Keterangan :}

Gambar 1. Desain Rancangan Eksperimen

X : Perlakuan/treatment (pemberian program "Aku Bisa ke Toilet Sendiri" berupa psikoedukasi orang tua, caregiver dan guru serta penerapan metode pembelajaran modeling selama dua minggu)

$\mathrm{O}_{1}$ : Pretest untuk Kelompok Eksperimen (mengisi skala keterampilan toileting sebelum pemberian perlakuan)

$\mathrm{O}_{2}$ : Posttest untuk Kelompok Eksperimen (mengisi skala keterampilan toileting seminggu setelah pemberian perlakuan)

$\mathrm{O}_{3}$ : Pretest untuk Kelompok Kontrol (mengisi skala keterampilan toileting sebelum pemberian perlakuan)

$\mathrm{O}_{4}$ : Posttest untuk Kelompok Kontrol (mengisi skala keterampilan toileting seminggu setelah pemberian perlakuan)

Adapun gambaran dari masingmasing program dapat dilihat pada Tabel 2 dan Tabel 3.

\section{Analisis data}

Uji statistik yang digunakan pada penelitian ini adalah uji Independent Sample T-Test bertujuan untuk melihat perbedaan skor antara dua kondisi subjek yang independen/berbeda Skor yang dibandingkan pada penelitian ini adalah gain score antara kelompok eksperimen dan kelompok kontrol. Adapun pengambilan keputusan pada penelitian ini berdasarkan perbandingan nilai $t$ hitung dengan $t$ tabel.

\section{Hasil}

Berdasarkan hasil analisis Independent sample T-test diketahui bahwa gain score pada penelitian ini merupakan data yang homogen dilihat dari tingkat signifikansi pada tabel Levene's test yang berada di atas taraf signifikansi yaitu sebesar 0,425 (sig $>0,05)$, sehingga untuk melakukan uji independent akan berpedoman pada tabel equal variances assumed. Berdasarkan tabel output independent sample test, Diketahui nilai $t$ hitung adalah sebesar 2,093 dengan $d f$ 14. Pada penelitian ini hipotesis yang diajukan ialah hipotesis terarah, sehingga menggunakan signifikansi 1-tailed. Dilihat dari distribusi nilai t-tabel dari baris $d f=14$ dan kolom 1-tailed sebesar 0,05 adalah 1,761 dengan taraf signifikansi 0,055 ( $p>0,05)$. Hasil analisis tersebut menunjukkan bahwa, tidak ada perbedaan skor yang signifikan antara kelompok eksperimen yang mendapat perlakuan berupa program "Aku Bisa ke Toilet Sendiri" dengan kelompok kontrol yang hanya mendapat perlakuan berupa pemutaran video yang bertemakan lagu-lagu mengenai toilet training.

\section{Diskusi}

Peningkatan mean pada kelompok eksperimen dikarenakan program "Aku Bisa ke Toilet Sendiri" disusun berdasarkan teori determinisme resiprokal Bandura, 
Tabel 2.

Gambaran Pelaksanaan Psikoedukasi Program "Aku Bisa ke Toilet Sendiri

\begin{tabular}{|c|c|c|}
\hline Nama Sesi & $\begin{array}{l}\text { Pengetahuan/ } \\
\text { Keterampilan }\end{array}$ & Definisi Operasional \\
\hline \multirow[t]{2}{*}{ Pengantar } & $\begin{array}{l}\text { Pengisian pretest \& } \\
\text { manipulation check }\end{array}$ & $\begin{array}{l}\text { Pengisian skala keterampilan toileting } \\
\text { serta pengisian lembar evaluasi } \\
\text { pemahaman materi }\end{array}$ \\
\hline & Building rapport & $\begin{array}{l}\text { Penjelasan mengenai agenda } \\
\text { psikoedukasi dan memberikan } \\
\text { motivasi kepada peserta untuk } \\
\text { mengikuti program hingga akhir. }\end{array}$ \\
\hline $\begin{array}{l}\text { Sesi } 1 \\
\text { Apa itu keterampilan } \\
\text { toileting }\end{array}$ & $\begin{array}{l}\text { Definisi, faktor yang } \\
\text { mempengaruhi serta } \\
\text { dampak dari kebiasaan } \\
\text { melakukan keterampilan } \\
\text { toileting }\end{array}$ & $\begin{array}{l}\text { Penjelasan mengenai definisi, faktor- } \\
\text { faktor yang memengaruhi } \\
\text { keterampilan toileting anak serta } \\
\text { menjelaskan seberapa penting dampak } \\
\text { keterampilan toileting bagi anak }\end{array}$ \\
\hline $\begin{array}{l}\text { Sesi } 2 \\
\text { Anak siap toileting }\end{array}$ & $\begin{array}{l}\text { Tahapan dan Tanda-tanda } \\
\text { kesiapan anak melakukan } \\
\text { toileting }\end{array}$ & $\begin{array}{l}\text { Memberikan penjelasan tanda-tanda } \\
\text { anak sudah dikatakan siap melakukan } \\
\text { toileting serta menjelaskan tahapan- } \\
\text { tahapan kesiapan anak secara tahapan } \\
\text { perkembangan }\end{array}$ \\
\hline $\begin{array}{l}\text { Sesi } 3 \\
\text { Apa yang harus } \\
\text { dilakukan }\end{array}$ & $\begin{array}{l}\text { Langkah-langkah, } \\
\text { pemberian motivasi dan } \\
\text { sikap yang ditunjukkan } \\
\text { ketika mengajarkan } \\
\text { keterampilan toileting }\end{array}$ & $\begin{array}{l}\text { Pemberian informasi terkait cara } \\
\text { memperkenalkan dan mengajarkan } \\
\text { keterampilan toileting dengan } \\
\text { menunjukkan sikap yang dibutuhkan } \\
\text { anak }\end{array}$ \\
\hline \multirow[t]{2}{*}{$\begin{array}{l}\text { Sesi } 4 \\
\text { Diskusi dan penutup }\end{array}$} & $\begin{array}{l}\text { Saling bertukar informasi } \\
\text { atau pengalaman saat } \\
\text { mengajarkan keterampilan } \\
\text { toileting pada anak }\end{array}$ & $\begin{array}{l}\text { Saling berbagi informasi terkait } \\
\text { pengalaman mengajarkan } \\
\text { keterampilan toileting ataupun } \\
\text { mendiskusikan masalah yang ditemui } \\
\text { ketika menerapkan keterampilan } \\
\text { toileting pada anak }\end{array}$ \\
\hline & $\begin{array}{l}\text { Pengisian lembar evaluasi } \\
\text { kegiatan, lembar evaluasi } \\
\text { pemahaman materi }\end{array}$ & $\begin{array}{l}\text { Pengisian lembar evaluasi kegiatan } \\
\text { dan lembar evaluasi pemahaman } \\
\text { materi setelah mendapat psikoedukasi }\end{array}$ \\
\hline
\end{tabular}

yang dalam penyusunan programnya tidak hanya melibatkan salah satu faktor tetapi juga mencoba memunculkan interaksi timbal balik antara tiga faktor utama. Program yang disusun ditujukan pada orang tua atau caregiver, guru serta anakanak. Pada penelitian ini dapat terjadi berbagai interaksi dari faktor-faktor 
Tabel 3.

Gambaran Pelaksanaan Metode Pembelajaran Modeling dengan Media Video

\begin{tabular}{|c|c|c|}
\hline Nama Sesi & $\begin{array}{l}\text { Komponen Kompetensi } \\
\text { Keterampilan Toileting }\end{array}$ & Definisi Operasional \\
\hline $\begin{array}{l}\text { Aku mau pipis } \\
\text { Aku mau eek }\end{array}$ & $\begin{array}{l}\text { Istilah-istilah yang digunakan dalam } \\
\text { kegiatan toileting }\end{array}$ & $\begin{array}{l}\text { Mengajarkan anak istilah-istilah } \\
\text { yang digunakan BAB dan BAK serta } \\
\text { menyebutkan tanda-tanda ingin } \\
\text { buang air kecil }\end{array}$ \\
\hline $\begin{array}{l}\text { Aku bisa ke } \\
\text { toilet sendiri }\end{array}$ & $\begin{array}{l}\text { Tahap-tahap dalam melaksanakan } \\
\text { kegiatan buang air kecil (BAK) serta } \\
\text { buang air besar (BAB) secara umum } \\
\text { terutama ketika di rumah }\end{array}$ & $\begin{array}{l}\text { Menjelaskan kepada anak tahap- } \\
\text { tahap melaksanakan kegiatan buang } \\
\text { air kecil (BAK) serta buang air besar } \\
\text { (BAB) secara umum terutama ketika } \\
\text { di rumah }\end{array}$ \\
\hline $\begin{array}{l}\text { Bu guru, } \\
\text { aku bisa ke } \\
\text { toilet sendiri }\end{array}$ & $\begin{array}{l}\text { Tahap-tahap dalam melaksanakan } \\
\text { kegiatan buang air kecil (BAK) serta } \\
\text { buang air besar (BAB) secara umum } \\
\text { terutama ketika di sekolah }\end{array}$ & $\begin{array}{l}\text { Menjelaskan kepada anak tahap- } \\
\text { tahap melaksanakan kegiatan buang } \\
\text { air kecil (BAK) serta buang air besar } \\
\text { (BAB) secara umum terutama ketika } \\
\text { di sekolah }\end{array}$ \\
\hline
\end{tabular}

sa ingin BAK atau BAB sehingga anak mulai memunculkan tindakan menggunakan toilet. 2) Faktor perilaku memengaruhi kognisi: ketika anak melakukan tindakan pergi ke toilet anak akan merasa lebih lega karena telah menghilangkan rasa/ keinginan BAK atau BAB nya sehingga membuat anak measa mampu mengembangkan kendali akan lingkungan interpersonalnya. 3) Faktor perilaku memengaruhi lingkungan: melihat beberapa anak masih belum mampu melakukan keterampilan toileting secara mandiri maka dirasa perlu menyusun suatu program yang melibatkan orang-orang di lingkungan anak untuk membiasakan anak melakukan toileting secara mandiri dan benar. 4) Faktor lingkungan memengaruhi perilaku: pada Program "Aku Bisa Ke Toilet Sendiri" membagi faktor lingkungan menjadi 2 yaitu lingkungan keluarga dan lingkungan sekolah. Bagaimana keluarga atau pengasuh memperkenalkan atau mengajarkan keterampilan toileting pada anak akan mempengaruhi perilaku keterampilan toileting yang ditujukan oleh anak. Begitupun ketika di sekolah, bagaimana cara sekolah menentukan metode pengajaran keterampilan toileting di sekolah akan memengaruhi kebiasaan keterampilan toileting anak di sekolah. 5) Faktor kognitif memengaruhi lingkungan: ketika anak sudah dapat menjalankan 4 proses penting dalam menjalankan metode pembelajaran modeling maka akan memunculkan positive reinforcement dari lingkungan anak. 6) Faktor lingkungan memengaruhi kognisi: ketika program berjalan lancar, di mana orang tua telah mendapat psikoedukasi maka orang tua mendapatkan informasi-informasi baru terkait toilet training dan mulai menerapkan 
cara untuk melatih keterampilan toileting anak di waktu yang tepat dengan cara yang sesuai dengan kebutuhan anak dan bagi anak program ini akan membuat anak mempelajari keterampilan toileting dengan cara yang lebih menyenangkan dan lebih mudah untuk diingat.

Pada pelaksanaan metode pembelajaran modeling partisipan mulai melakukan modeling perilaku keterampilan toileting yang dicontohkan oleh tokoh kartun pada video yang diputarkan. Seperti yang disampaikan oleh Bandura (1977) yang menyebutkan bahwa terdapat empat kondisi kunci yang diperlukan agar pembelajaran observasional atau modeling terjadi. Pada saat partisipan melakukan modeling, proses pertama yang dilalui oleh partisipan adalah proses attention atau atensi. Proses ini terjadi ketika partisipan mulai tertarik dan memberi perhatian yang selektif pada tokoh kartun yang berperan di dalam video serta secara akurat mulai memahami perilaku keterampilan toileting yang ditampilkan oleh tokoh kartun. Penyajian tahapan-tahapan keterampilan toileting juga disajikan satu per satu dan menyoroti setiap tahap secara terpisah juga membantu partisipan untuk melakukan pembelajaran observasional secara lebih baik.

\section{Menurut}

Bandura

pembelajaran observasioanl menunjukkan hasil yang lebih baik ketika perilaku yang kompleks dibagi menjadi beberapa bagian dan secara terpisah menampilkan atau menyoroti perilaku yang spesifik. Begitu juga penggunaan musik dan lagu. Abravanel, Levan-Goldschmidt, \& Stevenson (dalam Bandura, 1977) mengungkapkan bahwa anak-anak akan memberi perhatian yang lebih pada tindakan atau perilaku yang dicontohkan dengan menggunakan objek dan suara yang mencolok dibandingkan dengan memodelkannya secara diam-diam tanpa dibarengi dengan sesuatu yang mencolok.

Selanjutnya partisipan akan masuk pada proses retensi. Pada proses ini partisipan akan mulai mengodekan informasi mengenai tahap-tahap toileting menjadi simbol yang ringkas agar mudah diingat dan menyimpannya dalam ingatan atau memori sehingga informasi mengenai tahap-tahap melakukan toileting dapat diambil kembali dan mulai diterapkan ketika anak akan melakukan kegiatan BAK ataupun BAB. Setiap adegan yang ditampilkan oleh tokoh kartun dalam video menjadi sebuah simbol imajiner dalam bentuk gambar yang digunakan oleh partisipan untuk mengingat tahap-tahap toileting. Selain itu adanya narasi yang mendeskripsikan tahap-tahap toileting dengan kalimat yang sederhana dan dijelaskan secara berurutan sehingga dapat menjadi simbol verbal atau kode dari setiap tahap-tahap toileting. Memberi contoh gerakan pada setiap tahap dan memberikan instruksi kecil pada setiap tahap dengan tujuan untuk membantu partisipan membentuk kode atau simbol dari setiap tahapan toileting. Hal ini sejalan dengan apa yang diungkapkan oleh Rosenberg \& Simon (dalam Bandura, 1977) ketika simbol visual atau imajiner dan simbol verbal menyampaikan makna yang sama, anak akan mengintegrasikan informasi yang disajikan oleh modalitas yang berbeda ini ke dalam representasi konseptual yang umum. 
Proses selanjutnya adalah proses reproduksi, pada proses ini anak akan mengonversi representasi simbolis menjadi sebuah tindakan. Proses ini terjadi ketika anak sudah mampu meniru sikap serta tahap-tahap toileting yang dilakukan oleh model di dalam video. Partisipan menunjukkan perubahan perilaku secara bertahap, di awal setelah perlakuan partisipan terkadang masih belum melakukan setiap tahap secara benar sehingga masih perlu diingatkan. Hal ini sejalan dengan apa yang disampaikan oleh Bandura (1977), terkadang anak-anak masih bergantung pada yang orang lain katakan kepada mereka, karena mereka belum dapat sepenuhnya memonitor tindakan mereka sendiri.

Proses ke empat adalah proses motivasi. Proses motivasi terjadi ketika anak sudah berhasil melakukan toileting secara mandiri maka anak akan mendapatkan positive reinforcement berupa pujian atau reinforcement lainnya. Partisipan mulai menjelaskan dan mendemonstrasikan kepada eksperimenter dan observer bahwa mereka telah melakukan apa yang dicontohkan oleh tokoh kartun pada video, ketika situasi ini muncul guru kelas, ekperimenter dan observer memberikan reinforcement berupa pujian atau penghargaan berupa tepuk tangan ketika anak berhasil mengungkapkan apa yang telah partisipan terapkan saat melakukan toileting. Saat akan pulang sekolah, guru akan merangkum kegiatan belajar dan memberi pujian kepada siswa yang berani dan berhasil melakukan toileting secara benar dan mandiri. Selain itu ekperimenter juga memberikan stiker bintang kepada partisipan yang mampu melakukan tahapan toileting secara mandiri dan benar. Pemberian pujian dan stiker menjadi satu proses meningkatkan munculnya perilaku keterampilan toileting. Hal ini sejalan dengan penelitian yang dilakukan oleh Sari (2016) yang menunjukkan bahwa peningkatan kemandirian toileting anak dipengaruhi oleh suasana pembelajaran yang menyenangkan, motivasi, dan reward.

Pada saat psikoedukasi berlangsung, beberapa orang tua siswa mengajukan beberapa pertanyaan serta saling membagi pengalaman terkait cara-cara dalam melatih anak melakukan keterampilan toileting. Psikoedukasi yang dilakukan tidak hanya sebatas pembicara yang menyampaikan materi tetapi juga menjadi saran untuk saling berbagi informasi terkait keterampilan toileting di antara orang tua yang hadir. Sehingga diharapkan para orang tua dapat melatih anak keterampilan toileting dengan cara yang benar, di waktu yang tepat, dan memahami pentingnya keterampilan toileting bagi perkembangan anak. Seperti penelitian yang dilakukan oleh Machmudah (2017) yang menunjukkan bahwa pemberian psikoedukasi dengan metode demonstrasi video dan flash card berpengaruh terhadap peningkatan pengetahuan ibu dan keterampilan toileting anak toddler di sekolah toddler "Harapan Bunda" Surabaya. Pelaksanaan program yang dilakukan secara berkelompok baik dalam pelaksanaan pembelajaran modeling dan pada saat pelaksanaan psikoedukasi juga memengaruhi keberhasilan program ini seperti yang diungkapkan oleh hasil penelitian yang dilakukan oleh Law, Yang, Coit, dan Chan (2016) bahwa anak-anak yang mengalami kesulitan melakukan kegiatan toileting dan kemudian 
mendapatkan intervensi dengan melibatkan anak dan keluarga menunjukkan peningkatan keterampilan toileting yang lebih besar daripada anak-anak yang mengalami kesulitan melakukan kegiatan toileting yang hanya menjalani terapi individu.

\section{Kesimpulan}

Hasil ini menunjukkan bahwa program "Aku Bisa ke Toilet Sendiri" mampu meningkatkan keterampilan toileting anak dengan menerapkan model pembelajaran yang tepat serta dilaksanakan bersamaan dengan psikoedukasi yang diberikan kepada orang tua sehingga menambah pengetahuan orang tua dalam membantu mempertahankan kemandirian anak dalam melakukan keterampilan toileting dengan benar. Penerapan program menunjukkan bahwa pentingnya interaksi atau hubungan timbal balik antara tiga faktor utama dalam membentuk atau mengajarkan suatu perilaku baru seperti yang diungkapkan oleh Bandura (1977) dalam model determinisme resiprokal.

Saran

Program "Aku Bisa ke Toilet Sendiri" merupakan program yang disusun untuk meningkatkan keterampilan toileting anak yang lebih ditekankan pada faktor lingkungan yaitu lingkungan keluarga/caregiver serta lingkungan sekolah. Maka dari itu diharapkan penelitian ini dapat menjadi informasi kepada orang tua akan pentingnya keterampilan toileting bagi perkembangan anak. Selain itu orang tua dapat menjadikan media video sebagai alternatif untuk mengajarkan anak keterampilan toileting ketika berada di rumah.

Instansi pendidikan (Kelompok bermain, Taman Kanak-kanak, TPA) disarankan untuk menjadikan program ini salah satu alternatif yang dapat diterapkan untuk mengajarkan dan memunculkan perilaku mandiri dalam melaksanakan toileting saat di sekolah. Selain itu pada metode pembelajaran modeling, guru kelas memilik peran yang penting dalam proses pemberian motivasi kepada anak dengan memberikan positive reinforcement yang dapat berupa pujian atau stiker atau hal lain yang disukai anak agar mempertahankan kemandirian anak dalam melakukan toileting di sekolah.

Penelitian ini baru dilakukan dua kali pada kelompok siswa dengan jumlah sampel terbatas $(N<30)$. Oleh karena itu peneliti selanjutnya disarankan untuk menerapkan program ini dalam jumlah sampel penelitian yang lebih besar sehingga dapat mengetahui seberapa besar efektivitas dari program "Aku Bisa ke Toilet Sendiri" dengan membandingkan hasil dari beberapa kelompok.

\section{Kepustakaan}

Agustina, W., \& Sapta, R.F. (2015). Tiga faktor dominan penyebab kegagalan toilet training pada anak usia 4-6 tahun. Jurnal Ners dan Kebidanan, 2(2), 204-208.

doi:

\subsection{9/jnk.v2i2.ART.p188-192}

Bandura, A. (1977). Social learning theory. Englewood Cliffs, NJ: Prentice-Hall.

Brazelton, T. B. (1962). A child-oriented approach to toilet training. Pediatrics, 29(1), 121-128. 
Burns, C.O., \& Matson, J.L. (2017). Normal developmental milestones of toileting. In Matson J. (Eds), Clinical guide to toilet training children (hal. 49-62). Autism and Child Psychopathology Series. Springer.

Cocchiola M.A., \& Redpath, C.C. (2017). Special populations: Toilet training children with disabilities. In Matson J. (Eds), Clinical guide to toilet training children (hal. 227-250). Autism and Child Psychopathology Series. Springer.

Drysdale, B., Lee, C. Y. Q., Anderson, A., \& Moore, D. W. (2015). Using video modeling incorporating animation to teach toileting to two children with autism spectrum disorder. Journal of Developmental and Physical Disabilities, 27, 149-165. doi: 10.1007/s10882-0149405-1

Hasballah, M.U. (2017). Toilet training. Banda Aceh: CBK Publishing

Kaerts, N., Vermandel, A., Lierman, F., van Gestel, A., \& Wyndaele, J. J. (2012). Observing signs of toilet readiness: Results of two prospective studies. Scandinavian Journal of Urology and Nephrology, 46(6), 424-430. doi: $\underline{10.3109 / 00365599.2012 .693537}$

Law, E., Yang, J. H., Coit, M. H., \& Chan, E. (2016). Toilet school for children with failure to toilet train: Comparing a group therapy model with individual treatment. Journal of Developmental and
Behavioral Pediatrics, 37(3), 223-230. doi: $10.1097 / \mathrm{dbp} .0000000000000278$

Machmudah, M. (2017). Implementasi psikoedukasi toilet training melalui demonstrasi video dan flash card terhadap peningkatan pengetahuan ibu dan kemampuan toilet training anak toddler di Sekolah Toddler Harapan Bunda. Education and Human Development Journal, 2(1). doi: 10.33086/ehdj.v2i1.383

McLay L., \& Blampied N. (2017). Toilet training: Strategies involving modeling and modifications of the physical environmental. In Matson J. (Eds.), Clinical guide to toilet training children (hal. 143-167). Autism and Child Psychopathology Series. Springer.

Nurfajriyani. I, Prabandari. Y. S, \& Lusmilasari, L. (2016). Influence of video modelling to the toileting skill at toddler. International Journal of Community Medicine and Public Health, 3(8), 2029-2034. doi: 10.18203/23946040.ijcmph20162540

Sari, D.N.(2016). Modifikasi perilaku pendekatan positif dapat meningkatkan kemandirian anak (Skripsi tidak dipublikasikan). Surakarta: Universitas Muhamadiyah Surakarta. 